\title{
Finding Out the Influence of Marketing Mix on Attitude of Customers for Providing Online Reviews
}

\author{
Priyo Das ${ }^{\star 1}$; Pranam Dhar ${ }^{2}$ \\ ${ }_{1}^{1}$ Barrackpore Rastraguru Surendranath College, Kolkata, West Bengal 700120, India \\ ${ }^{2}$ Department of Commerce \& Management, West Bengal State University, Kolkata 700126, West Bengal, India \\ ${ }^{*}$ Correspondence E-mail: priyodas1996@gmail.com
}

Abstract

Unlike traditional market this modern competitive market includes a very important thing that motivates customers which is online reviews provided by existing customers. By keeping this situation in mind this study was focused on filling a very important research gap that is whether there is any influence of 4P's (Product, Price, Place and Promotion) of marketing mix influences customers the most for providing online reviews or not. For this purpose, Empirical research with descriptive cross-sectional research design was used and for the purpose of data collection convenience sampling method was utilized and data collected from 198 respondents. Before collecting the data, a pilot study with 44 respondents was used for analysing the reliability of data collection instrument. After finding the Cronbach's alpha value 0.933 , measurement model was utilized for checking the fit of proposed model and the model was validated based on several fit indices such as CMIN/df, GFI, CFI, SRMR and RMSEA as the values of each of them that is 2.080, .910, $0.943,0.050,0.076$ are less than the cut-off values that. in the end structural path model was used for seeing the direction of the constructs and also for testing hypotheses. The results based on completely statistics showing a very interesting direction and a conclusion that shows 4P's of marketing mix has no significant influence upon attitude customers for providing online reviews.

Keywords: 4P's of Marketing; Customers Attitude; Online Reviews

\section{Introduction}

With the booming development of technology in this $21^{\text {st }}$ century a new paradigm has been emerging strongly i.e., online marketing. Now-adays, buyers, by unlocking their cellular devices they get easily whatever they want whenever and wherever they want. This online market is slowly and steadily becoming a huge community where most of the buyers have been sharing their experience about every phenomenon (being that it is packaging, pricing, product receiving experience etc.) related to their purchase experience of a product. These reviews have an impact on prospective buyers whether positively or negatively many studies have shown online reviews puts a significant impact upon customers regarding purchase decision. Online reviews have an influence of satisfaction towards positive reviews through commitment of buyers, found by (Purnasari \& Yuliando, 2015). Credibility, quality and quantity of online reviews have directly motivated the buying intentions plus there is also a via effect of corporate image as well, found by (Bataineh, 2015). Trust in customers (prospective and existing) is influenced by the behavior of 
seller and online reviews and the sellers must have to pay attention on online reviews provided by customers, as found by (Alfina et al., 2014). This article was aimed to create and validate a research model of customer attitude towards providing online reviews with the independent variables of $4 p$ 's of marketing (such as product, price, place and promotion) (Janse \& Van Vliet, 2020), also focused to test hypotheses for reaching out to a conclusion. An understanding of the proposed model would be very beneficial for the sellers to understand the factors that lead a customer to provide online reviews.

\section{Review of Literature:}

The study of Filieri (2015), was based on dualprocess theory and he have extended its applicability to the online market and analysed the determinants of reviews diagnosticity from the perspective of customers and how this diagnosticity forces to adopt this review. His study concluded that the online reviews are having stronger effect and that information quality has extreme impact on online reviews. However, he also concluded that product rankings and ratings have a significant influence. whereas, source credibility has weak relationship; and quantity of review does not appear to influence their dependent variable. He affirmed that e-reviews with the highest level of quality and quantity are for buyers.

Duarte, Silva \& Ferreira (2018), adopted empirical research for achieving their research objective and for the purpose of data they utilized snow-ball sampling. The main ambition of their analysis was to analyse what breadth of convenience influences customers' satisfaction and offer reviews. They adopted constructs such as: satisfaction, e-WOM, and behavioral intentions and found that there is a deep connection between satisfied customers and providing online reviews. Their study showed an important relationship between the perceived online convenience and customer satisfaction. They have also found that consumers' convenience perception is highly influenced with firm related factors as well along with product related factors.
The study of Pérez \& Piñero (2012), qualifies Steffes \& Burgee's (2009) study by defining that online reviews have a greater influence than offline opinion leaders. For achieving their objective, they used empirical research by using one online tourism company after utilizing convenience sampling. Online reviews help in increasing its impact because customers can achieve lots of information online as compared to offline. They have also confirmed that the manipulation of online reviews on decision making and also influenced by demographics. Most importantly, gender and education have major impact in this process. They accomplished that the impact of e-WOM is superior for females and buyers with a lower level of education than for males and persons with a higher level of education.

The aim of the present study was to test the effect of CSR activities for consumers on social media on online reviews and buying intentions of the prospective buyers with the mediating consequence of brand attitude for banking sectors (Guping et al., 2021). They have used empirical research for achieving their purpose and for collection of data they have utilized convenience sampling method and for testing the anticipated model and attainment of conclusion Measurement and Structural model was used. They found and confirmed that customer CSR engagement on social media positively relates to online reviews and buying intentions. They also suggested that CSR activities should also be viewed as marketing technique because it leads to creation of huge online reviews.

\section{Product}

Riaz \& Tanveer (2012); Goi (2011) and Muala \& Qurneh (2012) uttered that Product can be defined as: "whatever thing that offered to the market for attentiveness, getting grip of, or consumption and fulfills some need". A seller should build up main product around the core utility of the product and then build augmented product around core and actual product.

Qualities, design, features of the offering, company name of the product are the main differential factors of a product plus pre and post 
sales services plays a major role and acceptance rate of a product is basically based on these factors.

\section{$H 1:$ There is an influence of product quality on customer attitude towards providing online reviews, \\ Price-}

Virvalaite, Saladiene \& Skindaras (2009) uttered that a price is crucial factor and it can be described as what been a customer given up-to for availing the product, customers' satisfaction is also depends on this factor. Consumers are generally estimating the value of obtained goods or service most by thinking about the price.

Riaz \& Tanveer (2012); Goi (2011) and Muala \& Qurneh (2012) found from many conceptual studies and suggested that price is actually monetary consideration or the entire values that consumers trade for the benefits of having the offerings of a company.

According to Chung \& Shin (2008); Nakhleh (2012) and Muala \& Qurneh (2012) the central role of price as a purchasing determinant as well as in post-purchasing processes is well recognized

It has been confirmed therefore, that consumers generally purchase products after considering the price rather than other attributes and it directly influences customer satisfaction.

H2: There is an impact of price on customer attitude towards providing online reviews, Place-

Riaz \& Tanveer (2012) suggested that Place means making a product available nearest to the customers. But Goi (2011) suggested that place means to how a company will distribute their products to the market.

A company should always pay attention to their place decisions, because customer generally purchase, and consumption occurs at the same place and same time; and satisfaction of their customer is greatly depending on this factor. Riaz \& Tanveer (2012) stated that branding strategies for place means that direct channels to achieve customers could be company owned stores, phone and e-selling whereas, indirect means selling by intermediaries such as distributors or agents. By using indirect channel, company loses control over distribution, selling and price. This might negatively affect the customers.

H3: There is an influence of distribution place of the product on customer attitude towards providing online reviews, Promotion-

Promotion means as sales promotion, advertising, personal selling, public relations and direct marketing which helps to make target market aware of the many choices available regarding products and services.

Communication is very crucial in marketing because it contributes 3 roles: providing information about product, persuading target market of a particular product, and motivating market to take action. Also, they can change a buyer's way of thinking, emotions, and understanding as well as their buying.

Promotional communication is crucial as it share information, suggestion, and it persuades the end market.

Riaz \& Tanveer (2012) stated that if an organisation or a product gets promoted without the organisation paying for it, it is called communication through Publicity. This type of communication has high credibility because it is seen as shared experience instead of an advertisement.

H4: There is an influence of promotional activities about a product on customer attitude towards providing online reviews, Research question, Problem statement and research gap-

What factors lead customers to provide online reviews about their purchase experience? After considering the importance online reviews in this $21^{\text {st }}$ century it can be said that, this is a very important question that needs to be answered by research. For this purpose, after going through a many study by keeping all the limitations in mind a research gap had been identified about online reviews. Still no study had been conducted before that put focus on whether there is any influence of 4P's (Product, Price, Place and Promotion) of 
marketing mix influences customers the most for providing online reviews or not.

\section{Objectives of study}

For making this research more practical and filling this gap, this study has two main objectives. This study aims

1. To propose a research model about customers attitude towards providing online reviews based on theory,

2. To analyse whether there is any influence of 4P's of marketing on the attitude of customers for providing online reviews.

\section{Methodology}

For the purpose of achieving the objectives of this study a well-planned research methodology was adopted, Empirical research was adopted with descriptive cross-sectional research design because this study includes collection of data on the basis of experience and testing of hypotheses for reaching out to a conclusion which means it is conclusive study. For the purpose of data collection, a questionnaire was designed after going through the theories and some literatures on this particular topic. After validating the questionnaire by a pilot study among 44 respondents with reliability analysis data had been collected by utilising convenience sampling the questionnaire was distributed among 198 respondents' residents of Khardah, Kolkata, West Bengal, India for collection of data. Convenience sampling was utilised because of the limited lock-down for COVID-19 (Corona Virus Disease). After collection of data Confirmatory Factor Analysis (CFA) was used to check the model fit. The reason behind choosing CFA is that this study was focused on developing and validating research model based on theories and based on previous work. Hypotheses were developed from the available literatures and after validating the model a structural path model was used for testing of the proposed hypotheses.

\section{Results and Discussion:}

Before going into data analyses part, a pilot test carried out for checking reliability of scales by taking 44 respondents and value of Cronbach's alpha is 0.33. shown in (table 1 and table 2)

Table 1: Case Processing Summary

\begin{tabular}{|l|l|l|l|}
\hline \multicolumn{2}{|c|}{} & N & \% \\
\hline Cases & Valid & 44 & 100.0 \\
\cline { 2 - 4 } & Excluded $^{\mathrm{a}}$ & 0 & .0 \\
\cline { 2 - 4 } & Total & 44 & 100.0 \\
\hline & $\begin{array}{l}\text { a. Listwise deletion based on all variables in } \\
\text { the procedure. }\end{array}$ \\
\hline
\end{tabular}

Table 2: Reliability Statistics

\begin{tabular}{|c|c|}
\hline Cronbach's Alpha & No of Items \\
\hline 0.933 & 21 \\
\hline
\end{tabular}

For data analysing purpose SEM technique was utilised. It is generally analysed by using two steps 1. Measurement model and 2. Structural model.

\section{Measurement model-}

Author checked measurement model after utilising CFA to evaluate the model fit in AMOS 23. The Chi-squared statistic was significant Chisquare $=122.73$, Degrees of freedom $=59$, Probability level $=.000$ However, Chi-squared statistics actually has a trade-off with the the sample size (Byrne, 2001). Figure 1 shows the measurement model which has 4 constructs and these 4 constructs were measured by 13 items. At the very beginning model's $\mathbf{X}^{2} / \mathbf{d f}$ were very high close to 5 which is not good for a model. Thus, after deletion of eight items from this theoretical model $\mathbf{X}^{2}$ Idf becomes 2.080. Items deleted from construct Product- Design and quality of the bought product is bad, from construct price- I don't consider price of a product if it's quality is very high from its alternatives, f rom construct placeI check Location of a shop or Place of delivery of a product before making purchase decision Review behavior- I prefer to provide online reviews about 


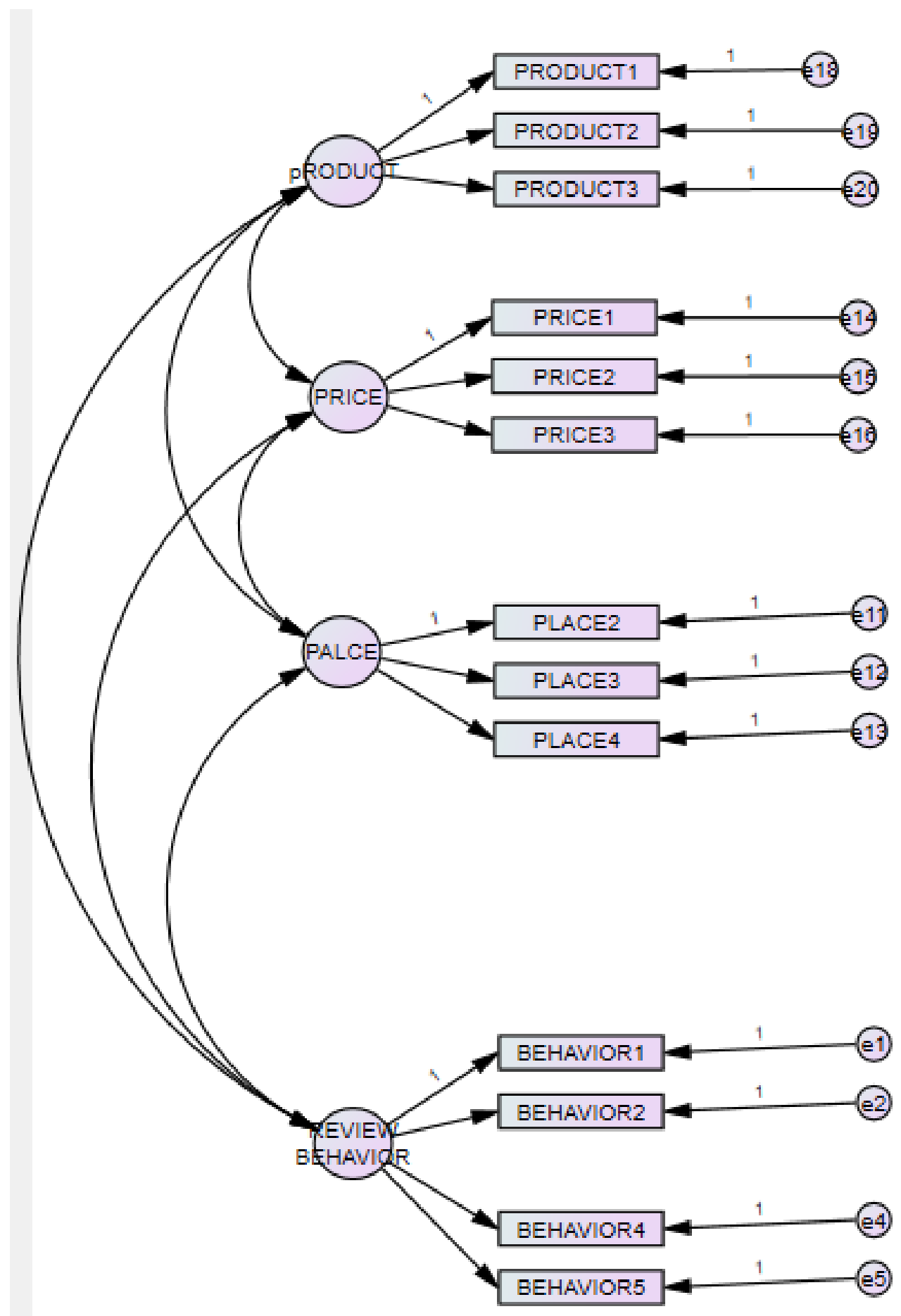

Figure 1: The Improved Model

the purchased product if shop location is good and the entire construct named promotion was deleted because that construct was degrading the values of GFI and CFI and their 'Standardised Residual Covariances' was also high. The values of model fit statistics are shown in table: 3 As we can see in table 3 , it gives us more improved model about customers reasons for giving online reviews (See figure 2). 


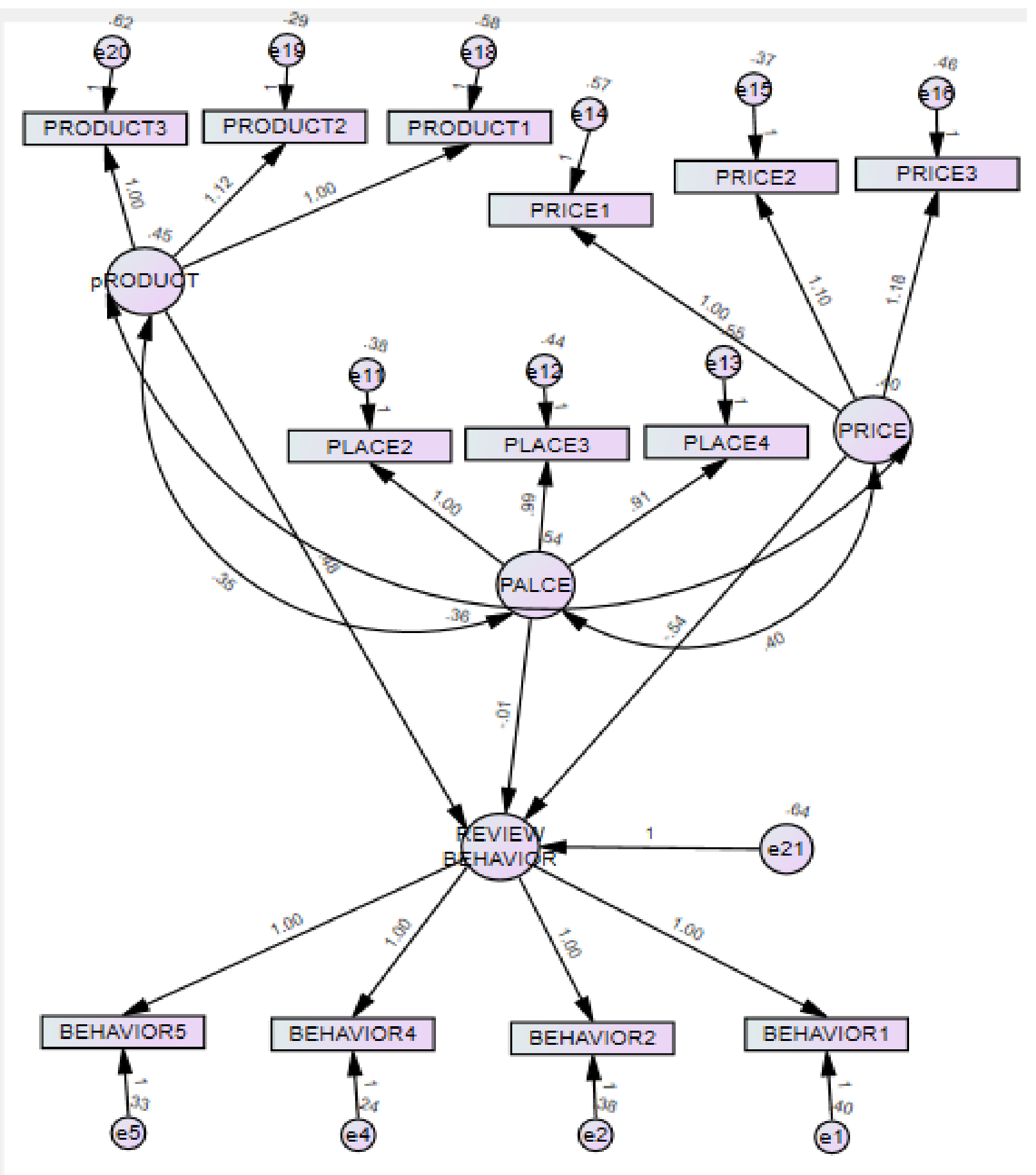

Figure 2: The Path Estimates

After this model fit discriminate and convergent validity were analysed by using AVE (Average Variance Extract) and Composite Reliability (CR), the value of AVE was more than the value .5 as well as the square of the correlations between the constructs. Values of square root of AVE, various correlations among factors and AVE are shown in table: 4 , table: 5 and table: 6 respectively and 
Convergent validity of each construct by using $\mathrm{CR}$ is equal to or more than value of 0.8 which is quite good. shown in table 7. So, this theory based hypothesised measurement model was appropriate for further analyses.

Discriminate validity analyse the extent to which items of a particular construct have a high degree of variation in general (Hair et al., 2010). It is achieved when AVE of every constructs with shared variances among it and others and this validity needs higher correlation value between the constructs (Fornell \& Larcker, 1981). Table 4 showing that AVE of the particular constructs are greater than .5 and more than the value of correlation between every construct i.e., AVE of Product, Price, Place, Review Behavior-, 0.5051, $0.714,0.59,0.619$ respectively.

Table 7 shows Product- 0.756, Price0.768, Place- 0.757 , Review behavior- 0.89. So, all the values of $\mathrm{CR}$ are equal to 0.8 or more than that so it clearly showed that the convergent validity is good enough. The convergent validity of this model is measured by standard regression weight. These results are reasonable and suggest that it is appropriate to proceed further with this model.

Table 3: Showing Model Fit Statistics

\begin{tabular}{|c|c|c|}
\hline $\begin{array}{c}\text { Model fit } \\
\text { Statistics }\end{array}$ & Estimate & $\begin{array}{c}\text { Cut-off } \\
\text { value }\end{array}$ \\
\hline CMIN & 122.73 & -------- \\
\hline DF & 59.00 & --------- \\
\hline PCMIN/DF & 2.080 & $1.00-3.00$ \\
\hline GFI & .910 & $>9$ \\
\hline CFI & 0.943 & $>0.95$ \\
\hline SRMR & 0.050 & $<0.08$ \\
\hline RMSEA & 0.076 & $<0.06$ \\
\hline
\end{tabular}

Table 4: Calculation of AVE for Discriminate Validity of Constructs

\begin{tabular}{|c|c|c|c|c|c|c|c|c|}
\hline Variables & & Constructs & $\begin{array}{c}\text { STANDARDI } \\
\text { SED } \\
\text { Loadings }\end{array}$ & $\begin{array}{c}\text { Square of } \\
\text { STANDAR } \\
\text { DISED } \\
\text { Loadings }\end{array}$ & $\begin{array}{c}\text { Sum of } \\
\text { square } \\
\text { STANDA } \\
\text { RDISED } \\
\text { Loading } \\
\text { s }\end{array}$ & $\begin{array}{c}\text { No. of } \\
\text { Indicators }\end{array}$ & AVE & $\begin{array}{c}\text { Square } \\
\text { root of } \\
\text { AVE }\end{array}$ \\
\hline BEHAVIOR1 & $<--$ & $\begin{array}{r}\text { REVIEW } \\
\text { BEHAVIOR }\end{array}$ & 0.829 & Estimate & \multirow[t]{4}{*}{2.479} & \multirow[t]{4}{*}{4} & \multirow[t]{4}{*}{0.6198} & \multirow[t]{4}{*}{0.787242} \\
\hline BEHAVIOR2 & $<--$ & $\begin{array}{r}\text { REVIEW } \\
\text { BEHAVIOR }\end{array}$ & 0.819 & 0.831 & & & & \\
\hline BEHAVIOR4 & $<--$ & $\begin{array}{r}\text { REVIEW } \\
\text { BEHAVIOR }\end{array}$ & 0.83 & 0.821 & & & & \\
\hline BEHAVIOR5 & $<--$ & $\begin{array}{l}\text { REVIEW } \\
\text { BEHAVIOR }\end{array}$ & 0.799 & 0.827 & & & & \\
\hline PLACE2 & $<-$ & Place & 0.765 & 0.796 & \multirow[t]{3}{*}{1.789544} & \multirow[t]{3}{*}{3} & \multirow[t]{3}{*}{0.5965} & \multirow[t]{3}{*}{0.772344} \\
\hline PLACE3 & $<--$ & Place & 0.738 & 0.544644 & & & & \\
\hline PLACE4 & $<--$ & Place & 0.67 & 0.4489 & & & & \\
\hline PRICE1 & $<--$ & PRICE & 0.645 & 0.647 & \multirow[t]{3}{*}{2.142} & \multirow[t]{3}{*}{3} & \multirow[t]{3}{*}{0.714} & \multirow[t]{3}{*}{0.844985} \\
\hline PRICE2 & $<--$ & PRICE & 0.757 & 0.76 & & & & \\
\hline PRICE3 & $<--$ & PRICE & 0.739 & 0.735 & & & & \\
\hline PRODUCT1 & $<--$ & Product & 0.659 & 0.434281 & \multirow[t]{3}{*}{1.515154} & \multirow[t]{3}{*}{3} & \multirow[t]{3}{*}{0.5051} & \multirow[t]{3}{*}{0.71067} \\
\hline PRODUCT2 & $<--$ & Product & 0.813 & 0.660969 & & & & \\
\hline PRODUCT3 & $<--$ & Product & 0.648 & 0.419904 & & & & \\
\hline
\end{tabular}

\section{Structural model-}

After conducting the above analysis, the structural path model was tested, and results of hypothesis are shown in table 8 . and figure 1 the structural path model. 
Table 5: Showing Various Correlations Among Factors

\begin{tabular}{|c|c|c|c|}
\hline Correlations & & & $\begin{array}{c}\text { Estima } \\
\text { te }\end{array}$ \\
\hline $\begin{array}{c}\text { REVIEW_BEHAV } \\
\text { IOR }\end{array}$ & $<-->$ & Place & $\begin{array}{c}- \\
0.085\end{array}$ \\
\hline $\begin{array}{c}\text { REVIEW_BEHAV } \\
\text { IOR }\end{array}$ & $<-->$ & Price & $\begin{array}{c}- \\
0.093\end{array}$ \\
\hline$\underset{\text { IOR }}{\text { REVIEW_BEHAV }}$ & $<-->$ & $\begin{array}{l}\text { Produ } \\
\text { ct }\end{array}$ & $\begin{array}{l}0.02 \\
9\end{array}$ \\
\hline PALCE & $<-->$ & Price & $\begin{array}{l}0.85 \\
7\end{array}$ \\
\hline PALCE & $<-->$ & $\begin{array}{l}\text { Produ } \\
\text { ct }\end{array}$ & $\begin{array}{l}0.70 \\
3\end{array}$ \\
\hline PRICE & $<-->$ & $\begin{array}{l}\text { Produ } \\
\text { ct }\end{array}$ & 0.81 \\
\hline
\end{tabular}

Table 6: Showing the AVE Values

\begin{tabular}{|c|c|c|c|c|}
\hline & $\begin{array}{c}\text { Produ } \\
\text { ct }\end{array}$ & price & $\begin{array}{c}\text { plac } \\
\text { e }\end{array}$ & $\begin{array}{c}\text { Review } \\
\text { Behavi } \\
\text { or }\end{array}$ \\
\hline Product & 0.72 & & & \\
\hline price & 0.8 & 0.85 & & \\
\hline place & 0.7 & 0.8 & 0.772 & 3 \\
\hline $\begin{array}{c}\text { Review } \\
\text { Behavi } \\
\text { or }\end{array}$ & 0.029 & -0.093 & - & 0.7872 \\
\hline
\end{tabular}

Values which are highlighted are the values of Squared Average Variance Extract (AVE) and rest are correlation among each construct.

Table 7: Calculation of Composite Reliability

\begin{tabular}{|c|c|c|c|c|c|c|c|c|c|c|}
\hline $\begin{array}{l}\text { Indicator } \\
\text { variables }\end{array}$ & & Factors & $\begin{array}{c}\text { Standar } \\
\text { dised } \\
\text { loadings }\end{array}$ & $\begin{array}{l}\text { squar } \\
\text { e of } \\
\text { Stand } \\
\text { ardise } \\
\text { d } \\
\text { loadin } \\
\text { gs (A) }\end{array}$ & $\begin{array}{c}\text { measur } \\
\text { ement } \\
\text { error }= \\
1-A\end{array}$ & $\begin{array}{c}\text { Sum of } \\
\text { the } \\
\text { measure } \\
\text { ment } \\
\text { error } \\
\text { (ME) }\end{array}$ & $\begin{array}{l}\text { Sum of } \\
\text { the } \\
\text { standardi } \\
\text { sed } \\
\text { loadings }\end{array}$ & $\begin{array}{l}\text { square } \\
\text { of the } \\
\text { sum of } \\
\text { the } \\
\text { standard } \\
\text { ised } \\
\text { loadings } \\
\text { (C) }\end{array}$ & $\begin{array}{l}\mathrm{C}+ \\
\mathrm{ME}\end{array}$ & $\begin{array}{c}\text { Compos } \\
\text { ite } \\
\text { reliabilit } \\
\text { y (CR)= } \\
\text { C/C+ME) }\end{array}$ \\
\hline BEHAVIOR1 & $<--$ & $\begin{array}{l}\text { REVIEW_BE } \\
\text { HAVIOR }\end{array}$ & 0.829 & $\begin{array}{c}0.6872 \\
41\end{array}$ & $\begin{array}{c}0.31275 \\
9\end{array}$ & \multirow[t]{4}{*}{1.314697} & \multirow[t]{4}{*}{3.277} & \multirow[t]{4}{*}{10.739} & \multirow[t]{4}{*}{$\begin{array}{c}12.0 \\
53\end{array}$} & \multirow[t]{4}{*}{0.890928} \\
\hline BEHAVIOR2 & $<--$ & $\begin{array}{l}\text { REVIEW_BE } \\
\text { HAVIOR }\end{array}$ & 0.819 & $\begin{array}{c}0.6707 \\
61\end{array}$ & $\begin{array}{c}0.32923 \\
9\end{array}$ & & & & & \\
\hline BEHAVIOR4 & $<--$ & $\begin{array}{l}\text { REVIEW_BE } \\
\text { HAVIOR }\end{array}$ & 0.83 & 0.6889 & 0.3111 & & & & & \\
\hline BEHAVIOR5 & $<--$ & $\begin{array}{l}\text { REVIEW_BE } \\
\text { HAVIOR }\end{array}$ & 0.799 & $\begin{array}{c}0.6384 \\
01\end{array}$ & $\begin{array}{c}0.36159 \\
9\end{array}$ & & & & & \\
\hline PLACE2 & $<--$ & Place & 0.765 & $\begin{array}{c}0.5852 \\
25 \\
\end{array}$ & $\begin{array}{c}0.41477 \\
5 \\
\end{array}$ & \multirow[t]{3}{*}{1.42123} & \multirow[t]{3}{*}{2.173} & \multirow[t]{3}{*}{4.7219} & \multirow[t]{3}{*}{$\begin{array}{c}6.14 \\
32\end{array}$} & \multirow[t]{3}{*}{0.768648} \\
\hline PLACE3 & $<--$ & Place & 0.738 & $\begin{array}{c}0.5446 \\
44\end{array}$ & $\begin{array}{c}0.45535 \\
6\end{array}$ & & & & & \\
\hline PLACE4 & $<--$ & Place & 0.67 & 0.4489 & 0.5511 & & & & & \\
\hline PRICE1 & $<--$ & Place & 0.645 & $\begin{array}{c}0.4160 \\
25 \\
\end{array}$ & $\begin{array}{c}0.58397 \\
5 \\
\end{array}$ & \multirow[t]{3}{*}{1.46481} & \multirow[t]{3}{*}{2.141} & \multirow[t]{3}{*}{4.5839} & \multirow[t]{3}{*}{$\begin{array}{c}6.04 \\
87\end{array}$} & \multirow[t]{3}{*}{0.757831} \\
\hline PRICE2 & $<--$ & PRICE & 0.757 & $\begin{array}{c}0.5730 \\
49\end{array}$ & $\begin{array}{c}0.42695 \\
1\end{array}$ & & & & & \\
\hline PRICE3 & $<--$ & PRICE & 0.739 & $\begin{array}{c}0.5461 \\
21\end{array}$ & $\begin{array}{c}0.45387 \\
9\end{array}$ & & & & & \\
\hline PRODUCT1 & $<--$ & PRODUCT & 0.659 & $\begin{array}{c}0.4342 \\
81\end{array}$ & $\begin{array}{c}0.56571 \\
9\end{array}$ & & & & & \\
\hline PRODUCT2 & $<--$ & PRODUCT & 0.813 & $\begin{array}{c}0.6609 \\
69\end{array}$ & $\begin{array}{c}0.33903 \\
1\end{array}$ & & & & & \\
\hline PRODUCT3 & $<--$ & PRODUCT & 0.648 & $\begin{array}{l}0.4199 \\
04\end{array}$ & $\begin{array}{c}0.58009 \\
6\end{array}$ & & & & & \\
\hline
\end{tabular}




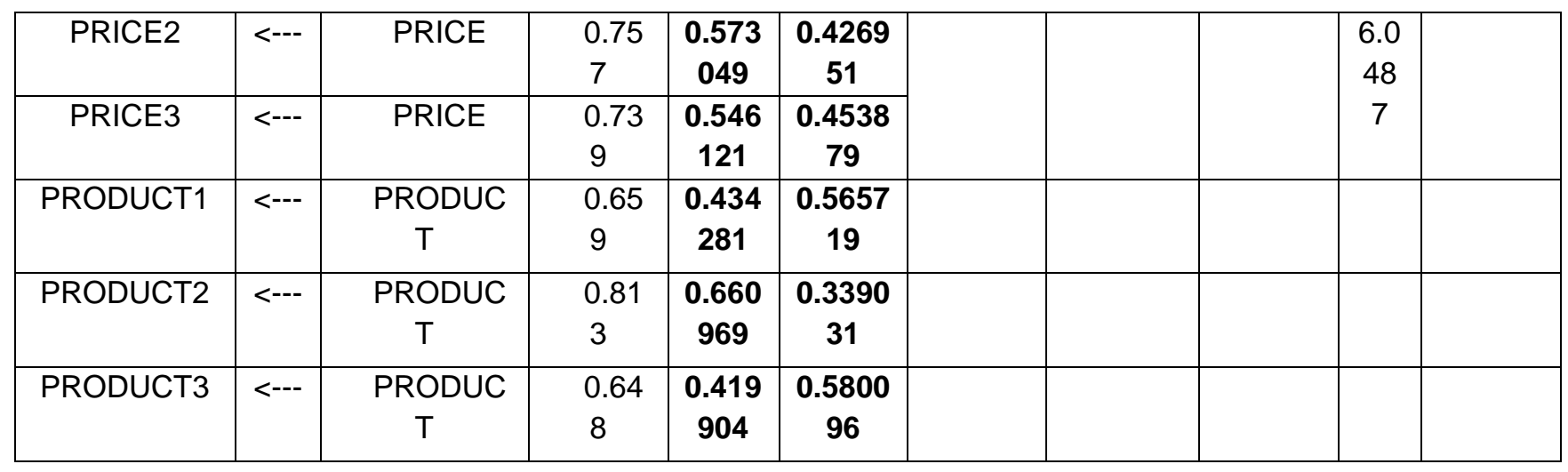

Table 8: Maximum Likelihood Estimates

\begin{tabular}{|l|c|c|c|c|c|c|}
\hline & & & Estimate & S.E. & C.R. & P \\
\hline & & & & & & \\
REVIEW_BEHAVIOR & $<---$ & Product & 0.483 & 0.351 & 1.378 & 0.168 \\
\hline & & & & & & \\
REVIEW_BEHAVIOR & $<---$ & Place & -0.008 & 0.31 & 0.025 & 0.98 \\
\hline & & & & & & \\
REVIEW_BEHAVIOR & $<---$ & Price & -0.543 & 0.585 & 0.928 & 0.354 \\
\hline
\end{tabular}

Table 9: Hypotheses Test Results

\begin{tabular}{|l|l|l|}
\hline Hypotheses & Estimates & results \\
\hline $\begin{array}{l}\text { H1: There is an influence of product quality on customer attitude } \\
\text { towards providing online reviews }\end{array}$ & 0.483 & $\begin{array}{l}\text { Not } \\
\text { Supported }\end{array}$ \\
\hline $\begin{array}{l}\text { H2: There is an impact of price on customer attitude towards providing } \\
\text { online reviews, }\end{array}$ & -0.543 & $\begin{array}{l}\text { Not } \\
\text { Supported }\end{array}$ \\
\hline $\begin{array}{l}\text { H3: There is an influence of distribution place of the product on } \\
\text { customer attitude towards providing online reviews, }\end{array}$ & -0.008 & $\begin{array}{l}\text { Not } \\
\text { supported }\end{array}$ \\
\hline $\begin{array}{l}\text { H4: There is an influence of promotional activities about a product on } \\
\text { customer attitude towards providing online reviews }\end{array}$ & $\begin{array}{l}\text { Not Tested. (see data } \\
\text { analysis part) }\end{array}$ \\
\hline
\end{tabular}

\section{Conclusion:}

An online review about a company's offering plays a great role of digital opinion leaders and as found in literature reviews and previous studies online reviews heavily influence buyers. This is very much important because in reality it can be observed that prospective customers depend widely upon these online reviews and yet it is unknown that which factor actually influences the customers immensely to provide online reviews. The basic aim of this study was to find whether there is any influence of 4P's of marketing mix on the attitude of customers for providing online reviews and after conducting this study and analysing data and after adjusting some values based on measurement model by deleting factor named promotion due to model fit errors, (see figure 2) it is found that the proposed theoretical hypothesised model is a fit model (see table 3) 
and after testing hypotheses (see table 9), statistically it might be concluded that customers don't provide reviews on the basis of product quality, price of the product and place of the delivery and promotional activities related to product. By keeping the findings and previous studies in mind it can be recommended that companies should provide major emphasis on every aspect of their offerings because still it is not clear that which factor influences the customers more to provide online reviews. The model that is created in this study is a fit model based on statistics (see table 3) can be further utilised for various study and some specific sectors like FMCG or Hospitality must be checked for finding more specific results.

\section{Acknowledgments:}

The author is thankful to the institutional authority for completion of the work.

\section{Conflicts of Interest:}

The authors declare that the research review was conducted in the absence of any commercial or economic associations that could be construed as a potential conflict of interest.

\section{References}

Al Muala, A., \& Al Qurneh, M. (2012). Assessing the relationship between marketing mix and loyalty through tourists satisfaction in Jordan curative tourism. American Academic \& Scholarly Research Journal, 4(2), 1.

Alfina, I., Ero, J., Hidayanto, A. N., \& Shihab, M. R. (2014). The impact of cognitive trust and e-wom on purchase intention in $\mathrm{C} 2 \mathrm{C}$ e-commerce site. Journal of Computer Science, 10(12), 2518.

Bataineh, A. Q. (2015). The impact of perceived eWOM on purchase intention: The mediating role of corporate image. International Journal of Marketing Studies, 7(1), 126.

Byrne, B. M. (2001). Structural equation modeling with AMOS: Basic concepts. Applications, and Programming, Mahwah, New Jersey.

Chung, K. H., \& Shin, J. I. (2008). The relationship among e-retailing attributes, e-satisfaction and eloyalty. Management Review: An International Journal, 3(1), 23-45.
Duarte, P., e Silva, S. C., \& Ferreira, M. B. (2018). How convenient is it? Delivering online shopping convenience to enhance customer satisfaction and encourage e-WOM. Journal of Retailing and Consumer Services, 44, 161-169.

Filieri, R. (2015). What makes online reviews helpful? A diagnosticity-adoption framework to explain informational and normative influences in e-WOM. Journal of Business Research, 68(6), 1261-1270.

Fornell, C., \& Larcker, D. F. (1981). Evaluating structural equation models with unobservable variables and measurement error. Journal of marketing research, 18(1), 39-50.

Goi, C. L. (2011). Perception of consumer on marketing mix: Male vs. female. In 2010 International Conference on Business and Economics Research (Vol. 1).

Guping, C., Cherian, J., Sial, M. S., Mentel, G., Wan, P., Álvarez-Otero, S., \& Saleem, U. (2021). The relationship between csr communication on social media, purchase intention, and e-wom in the banking sector of an emerging economy. Journal of Theoretical and Applied Electronic Commerce Research, 16(4), 1025-1041.

Hair Jr, J., Black, W., Babin, B., \& Anderson, R. (2010). Multivariate data analysis a global perspective. Pearson Education Inc. USR, New Jersey, 7458.

Janse, B, \& Van Vliet, V. (2020). Marketing mix 4P 's (McCarthy).

https://www.toolshero.com//marketing/marketingmix-4p-mccarthyl

Nakhleh, K. (2012). Globalized Palestine: The national sell-out of a homeland. Red Sea Press.

Pérez, M. L., \& Piñero, M. S. (2012). The Impact of e-WOM: determinants of Influence. In Advances in Advertising Research (pp. 217-232).

Purnasari, H., \& Yuliando, H. (2015). How relationship quality on customer commitment influences positive e-WOM. Agriculture and Agricultural Science Procedia, 3, 149-153. 
Riaz, W., \& Tanveer, A. (2012). Marketing mix, not branding. Asian Journal of Business and Management Sciences, 1(11), 43-52.

Steffes, E. M., \& Burgee, L. E. (2009). Social ties and online word of mouth. Internet Research.
Virvalaite, R. Saladiene, V., \& Skindaras, D. (2009). The relationship between price and loyalty in services industry. Enineering Economics, 63(3). 